\title{
Correction to: The Peacock study: feasibility of the dynamic characterisation of the paediatric hypothalamic-pituitary-adrenal function during and after cardiac surgery
}

Daniel Paul Fudulu ${ }^{1,2^{*}}$, Gianni Davide Angelini', Fani Fanoula Papadopoulou ${ }^{3}$, Jonathan Evans ${ }^{4}$, Terrie Walker-Smith ${ }^{4}$, Ido Kema ${ }^{5}$, Martijn Van Faassen ${ }^{5}$, Serban Stoica ${ }^{3}$, Massimo Caputo ${ }^{3}$, Stafford Lightman ${ }^{2}$ and Benjamin Gibbison ${ }^{6}$

Correction to: BMC Cardiovasc Disord 20, 245 (2020) https://doi.org/10.1186/s12872-020-01516-y

Following publication of the original article [1], the authors identified an error in the author name of be Martijn van Faassen.

The incorrect author name is: Martijn van Fassen The correct author name is: be Martijn van Faassen The original article [1] has been updated.

\begin{abstract}
Author details
${ }^{1}$ Department of Cardiac Surgery, Bristol Heart Institute, Bristol, UK. ${ }^{2}$ Henry Welcome Laboratories for Integrative Neuroscience and Endocrinology, University of Bristol, Bristol, UK. ${ }^{3}$ Department of Congenital Heart Surgery, Bristol Royal Hospital for Children, Bristol, UK. ${ }^{4}$ Clinical Trial and Evaluation Unit, University of Bristol, Bristol, UK. ${ }^{5}$ Department of Laboratory Medicine, University of Groningen, Groningen, Netherlands. ${ }^{6}$ Department of Cardiac Anaesthesia, Bristol Heart Institute, Bristol, UK.
\end{abstract}

Published online: 08 June 2020

\section{Reference}

1. Fudulu, et al. The Peacock study: feasibility of the dynamic characterisation of the paediatric hypothalamic-pituitary-adrenal function during and after cardiac surgery. BMC Cardiovasc Disord. 2020;20:245 https://doi.org/10.1186/ s12872-020-01516-y.

The original article can be found online at https://doi.org/10.1186/s12872 020-01516-y.

* Correspondence: danielfudulu@gmail.com

'Department of Cardiac Surgery, Bristol Heart Institute, Bristol, UK

${ }^{2}$ Henry Welcome Laboratories for Integrative Neuroscience and Endocrinology, University of Bristol, Bristol, UK

Full list of author information is available at the end of the article

C C The Author(s). 2020 Open Access This article is licensed under a Creative Commons Attribution 4.0 International License, which permits use, sharing, adaptation, distribution and reproduction in any medium or format, as long as you give appropriate credit to the original author(s) and the source, provide a link to the Creative Commons licence, and indicate if changes were made. The images or other third party material in this article are included in the article's Creative Commons licence, unless indicated otherwise in a credit line to the material. If material is not included in the article's Creative Commons licence and your intended use is not permitted by statutory regulation or exceeds the permitted use, you will need to obtain permission directly from the copyright holder. To view a copy of this licence, visit http://creativecommons.org/licenses/by/4.0/ The Creative Commons Public Domain Dedication waiver (http://creativecommons.org/publicdomain/zero/1.0/) applies to the data made available in this article, unless otherwise stated in a credit line to the data. 